\title{
Cultural Hegemony in Best Works of Jakarta Art Council Novel Award 2018
}

\author{
Farah Lumongga Harahap ${ }^{1}$, Tommy Christomy ${ }^{2}$ \\ Faculty of Humanities, Universitas Indonesia, Depok \\ $\left\{\right.$ monggaharahap@,gmail.com $^{1}$; tommy.christomy@ui.ac.id $\left.{ }^{2}\right\}$
}

\begin{abstract}
Oftentimes, literary works could uncover things that couldn't be covered by mass media. The cries of the people are expressed by writers through various ways. This research discusses the hegemony that is shown through the focalizer in Jakarta Art Council Novel Award 2018 for best works, which are Orang-Orang Oetimu [7], Anak Gembala yang Tertidur Panjang di Akhir Zaman [5], and Balada Supri [6]. These novels are chosen because they share the same underlying themes about the condition of minorities. The theory used in this paper is Antonio Gramsci's Cultural Hegemony through which is identified through focalization in the three novels so that the perspective and opinions of the focalizer is revealed [9]. The findings show that (1) violence is legalized by the authority as a tool to establish hegemony, (2) religion is used a means to silence the people's outcry, (3) social construction to maintain hegemony, and (4) counter-hegemony characters are oppressed by the ruling class. Despite this, at times the writer inadvertently falls into the hegemony itself by perpetuating discriminatory ideas about women and using religion as a means of escaping the hegemonic structure even though it is a tool of hegemony itself.
\end{abstract}

Keywords: Minorities, Jakarta Art Council, Hegemony, Novel, Focalization

\section{Introduction}

This research discusses the form of hegemony that is displayed through the focus of the three winning novels of the Jakarta Art Council Novel Award 2018. Novels are worldrecognized media for social expression. It has their own way of questioning social life as seen in the winning novels of the 2018 Jakarta Arts Council Novel Award. The issues of power and domination are presented in a literary way. The hegemony seen in this novel is in the form of cultural hegemony, religious hegemony, counter-hegemony, and hegemonic masculinity.

Humanitarian issues are presented through the experiences of characters in literary works brought up in the three novels won by the Jakarta Art Council Novel Award 2018, namely Orang-Orang Oetimu [7] by Felix K. Nesi, Anak Gembala Yang Tertidur Panjang di Akhir Zaman [5] (AGTPAZ) by A. Mustafa, and Balada Supri [6] by Mochammad Nasrullah. These three novels raise the fate of marginalized people as the core of the story, such as transgender people, the Ahmadiyah religious sect, small villages in NTT, fishermen, and people who are considered communists. The three of them also have an element of strong religiosity, that is, religion is the center of life for the characters in it. Also, these novels raise the marginalization of minorities. 
Past research on the depiction of hegemony in literary works has been explored before ([8]; [9]). Cultural hegemony in Orang-Orang Oetimu [7] has been discussed before as an article using a sociological approach for literary works which in descriptive research. Discussions regarding the Jakarta Art Council have also been discussed before [11]. However, no research specifically discusses how cultural hegemony towards the minority is used in literary works using focalization theory, especially in Indonesia. Therefore, this research focuses on the various forms of hegemony in three literary works that try to express the people's outcry by analyzing the focalization contained in the novels. The purpose of this research is to give a detailed explanation of how hegemony is formed, operated, and maintained in literature.

\section{Research Methods}

Thus, my research procedure is (1) determining the corpus; (2) take readings to find expressions and patterns related to the research objectives; (3) describe the findings, and (4) conclude the analysis and findings. Through this method, the results of temporary research were found, including the existence of forms of cultural hegemony, hegemonic masculinity, and counter-hegemony in the three winning novels of the Jakarta Art Council Novel Award 2018. There were also pieces of evidence of the two authors from the three winners, namely A. Mustafa and Mochammad Nasrullah. The theory used is the hegemony theory by Antonio Gramsci [9] and Mieke Bal's focalization in About Literature [4].

In this study, researchers will use the concept of hegemony from Gramsci with the concept of focalization Mieke Bal in About Literature [4] which was translated by Akhdiati Ikram. According to Bal [4], focalization is a way of looking at an event from a certain point of view. The subject of viewpoint or viewers is referred to as a focalizer. Focalizer is divided into three, namely external focalist, internal focalist, and collective focalistator.

Cultural hegemony is a condition when the effort to gain power is not utilizing violence but by creating acceptable conditions. This hegemony creates a condition that seems and is indeed beneficial, both for the dominant and the classes under it. Furthermore, the concept of Gramsci's counter-hegemony is the process of the subordinate class challenging dominant hegemony and trying to replace it by articulating hegemony [9]. The conditions given by the authorities tend to be undemocratic and inviolable so that there is no better choice but to submit to hegemony. Finally, hegemonic masculinity is the application of hegemony in gender. This form of hegemony can be found through the actions of men acting against women, homosexuals, and people who have an economic level and masculinity below. Hegemony does not always mean non-violence even though it can be supported by violence; he lives in culture, institutions, and persuasion [9].

\section{Results and Discussion}

\subsection{Hegemony Between State Apparatus and Society}

Community life is not only determined by each individual. The government is heavily involved in determining the fate of the people. The screams of suffering and people's lives cannot be directly conveyed or inscribed in history. Marginalized communities, who are marginalized, are the decisions and actions of the government. The practice of hegemony does not always survive by mutual agreement. This practice is protected by the shield of coercion, 
namely coercion through threats and intimidation [3]. Therefore, the government and the authorities need the apparatus and army to maintain power with the lure of public security and national unity.

State officials are presented in various conflicts through the focalization of characters and citizens in the winning novel of the Jakarta Art Council Novel Award 2018. The public does not have power or even objections in dealing with the apparatus. This is shown in Orang-Orang Oetimu [7] that citizens can only keep their mouths shut because they are state officials acting on behalf of the state. If they fight, they will be considered communists who deserve to be killed [7]. The absence of resistance from local residents is a form of the practice of hegemony so that it seems as if there is a mutual agreement that Sergeant Ipi can do whatever he wants.

Apart from the police, soldiers are also depicted as not having to be responsible for the crimes they have committed. The presence of the army raises both respect and terror because it often takes the lives of innocent civilians. The residents kept their distance when the incident occurred because they understood that the fate of an eyewitness would only end up behind the cell [7]. This condition often happened: it was not said that the soldiers were being tried and eyewitnesses were the victims of sin. Besides, external focalists explained that having paid officers to give speeches at civilian funerals was a solution and evidence that this continued during the East Timor war.

The same thing is also explained in Balada Supri [6]. From the Colony era until after the New Order, people are said to have remained under repression by the authorities. Matters that still reek of assumptions without evidence that are considered threatening must immediately be sidelined if they do not submit to the authorities. This happened to three generations, starting from Djoko Telu, Djoko Tole, to Supri Kumbang. They have to get out of people's lives if they still want to live. However, the proxies of the ruler were everywhere and took various forms, for example as police, company translators, hired pirates, employees of large ships, and residents.

The criticism given by the state apparatus is also present in AGTPAZ [5]. Paguyuban Waria Tri Lomba Juang (PAWATRI), an organization that protects transgender people and the first LBGT in Semarang, was established and collaborated with the mayor of Semarang and the authorities to prevent them from acting arbitrarily. However, the authorities did not hesitate to break the written agreement and under the law because of Yuli's carelessly throwing stones at the car which flooded her body with puddle water. As a result, the red plate car reported the incident to the police, then ended the fate of Rara Wilis as chairman of PAWATRI [5]. Even though there is a legal agreement between Pawatri, the city government, and the police so that transgender women are not disturbed. The marginalization of minorities also occurs. The New Order set depicts a similar thing in this novel, the burning of businesses belonging to people of Chinese descent and the mass murder of people suspected of being communists [5].

In the three novels, it was found that the apparatus that was supposed to maintain order were abusing their authority. Through citizen focalizers and figures, no one can oppose the apparatus because of their power that is motivated by the government. Also, the police and army who were won in the three stories are proof that hegemony is absolute because it uses various aspects and methods to maintain power. Hegemony in this case affects the resilience system and runs on the mutual agreement because the apparatus benefits from the absence of responsibility that must be paid for their actions and society. Communities seem to have no right and power to vote to object to changes in systems and practices.

\subsection{Social and Community Construction}


Coercion and repression are not the only means of maintaining hegemony. The authorities carry out various means to get the consent of the workers, whether consciously or not. Hegemony, through social construction, is exercised through the suppression and exaltation of men.

The hegemonic masculinity carried out in Orang-Orang Oetimu [7] proves something other than the subordination of women. Male characters who are hegemonic to masculinity are also victims of hegemonic masculinity itself. This is expressed through the act to act that jumps but converges into an event. One of the evidences of a male character who practices this hegemonic masculinity is Linus Atoin Aloket. Women are only used as consolation sex objects. However, he lost to the hegemony that lived and was trusted to the bone marrow. "At the forty-four woman, Linus gave up. God curses him. He was barren [7]".

Sergeant Ipi remains a victim. As the village ruler, he was never shown to bully or abuse women. Little Ipi went to the house of Naef Ahelet, the village circumcision shaman, to have his genitals examined, which was twice as big as his friend. Once there, Ipi ended up being harassed because Naef Ahelet was lust because he saw the size of Ipi's genitals. Incidents of sexual harassment led to Ipi's masturbation addiction. Focalizer Sgt Ipi as a state apparatus "lost" to the social construction created to protect himself and the ruler.

In Balada Supri [6], hegemonic masculinity takes on a different form from Orang-Orang Oetimu [7]. The social construction of women's labeling and stereotypes, as well as the size of male genitalia, often occurs in Balada Supri [6]. Names, such as "His Talking Wife", "His Talking Mother", "The Fat One", continued from the beginning to the end of the story. Even the social construction that women must be virgins when married to their husbands and whether or not virgins are determined by blood is still being discussed. Hegemonic masculinity has never been questioned. Rara Wilis in $A G T P A Z$ [5] as shemale who are often humiliated by people who feel more masculine than shemale. Because of this sense of masculinity, male figures feel they can oppress transgender people. This was shown by the vocalist Rara Wilis who was raped by Haris who forced her to make love again [5].

Based on these three novels, it can be seen that hegemonic masculinity is a tool to maintain power, both the rulers themselves and men who tend to be in the top positions. Subordination, physical violence, and the rape of women are depicted in all three novels. Gendered social construction takes its toll on the men themselves.

\subsection{Hegemony of Religion and Society}

To complement and facilitate the submission of the working-class society to the capital owner class, the rulers launched religion as a shortcut from all the rigors and disappointments of the society below them. It is said that religious leaders continued to offer invitations to kindness to their followers which they later violated. Patience and prayers are continuously served to avoid the demands of the followers of his teachings.

In Orang-Orang Oetimu [7], pastors and priests continue to practice religion. Priests are deemed entitled to give little or no wages to small people, such as an orphan and a runaway female worker [7]. The deaths that occurred due to the late delivery of the drugs blamed the residents who went to the shaman [7]. The giving of small wages on the pretext of religion and dedication also took place at Santa Helena High School led by Father Yosef. The facilitators of the rescued female workers explained how religion can calm someone's heart and avoid objections. Father Yosef and Father Laurentius illustrate the construction of religion that is built-in society so that no one can question and blame an action on another action without any logical connection between the two. 
The same thing is also found in $A G T P A Z$ [5], namely religion as an ironic solace and a means of maintaining power. Rara Wilis, who was selling herself, was almost killed by a santri (Islamic boarding school student) because she was a shemale and a prostitute. The santri focalist and Haji Gozali are a form of how hegemony works through religion. A person who is considered heretical is destroyed or marginalized, not invited to go on a path that is considered right. Also, religion as a tool of hegemony makes it easier for the people under it to move without realizing that they are being led. Pak Wo figures, Rara Wilis who has repented, was expelled by local government officials and Haji Gozali because he is an Ahmadi, considered heretical and deserves to be expelled. The ironism of religious leaders was expressed through the vocalist Haji Gozali, who urged people to respect their fellow God's creatures, instead, they supported the expulsion of Pak Wo from the mosque environment.

The same thing happened in Balada Supri [6], but the tendency towards magic was more highlighted than religion. Djaka, Djoko Telu, and Djoko Tole are three generations capable of practicing Mountain Waves. The three figures were present as a counter-hegemony in their way. However, they depend on the same thing, namely their magic and their proximity to the sea. The resolution of the conflict between the rulers, the company, and the owners of the big ships, was resolved with chanting passed down from across generations. Through the focalist Djoko Telu and Djoko Tole, we can see that ordinary citizens cannot defeat the hegemony of the rulers unless they ask for help from other magical parties. Even so, the results they got were the same, namely elimination and death. The owners of capital only suffer losses and anxiety, while the counter-hegemony promoters can still be overcome and defeated.

Through the three novels, it is revealed that religion is one of how the ruler survives his power. As Hicks [2] has explained, religion is used for political purposes by utilizing religious institutions and religious leaders to marginalize people. In this case, the rulers benefit because with a strong religion there will be no riots and protests against the bourgeoisie or the government but destroy the justice and welfare of society which will never be raised. Focalizer of religious leaders is a tool of hegemony in reducing conditions so that only hope through God can a worldly problem be resolved. Besides, the three novels describe the cruelty of religious hegemony. Adherents follow the things said by religious institutions or leaders in the name of faith so that behavior tends to be without consideration.

\subsection{Counter-Hegemony and Society}

Hegemony tends to be absolute so that its power cannot be tampered with. However, efforts to eradicate hegemony continue to be present in these three novels, both consciously and unconsciously through the characters. The attempt to defeat hegemony or at least give the proletariat the awareness that they are oppressed is called a counter-hegemony.

In Orang-Orang Oetimu [7], counter-hegemony is present as a female figure. Focalizer Maria, from the time she was a student and after the death of her child and husband, was aware of and demanded government equality and justice. The vocalist Maria, who continues to reveal and demand the truth, ends up committing suicide because she is unable to face reality. Focalist Silvy shares the view that the teachers at Santa Helena High School, the best school, cannot beat the intelligence of a poor pickpocket's child. Silvy's intelligence makes the teachers doubt the truth. Because the teacher's power was distracted by Silvy, the teachers were restless and reported it to Father Yosef. Silvy's fate ended up in the Reading Room as a silence so that the students were forgotten, and the teacher was not disturbed.

Silencing and marginalization were also found in Balada Supri [6]. Counter-hegemony figures, such as Djoko Tole's wife who was talkative, were marginalized by society because of her innocence and honesty. Also, Djoko Tole and Djoko Telu are counter-hegemony figures 
who continue to sail alone without submitting to the armpits of large ship owners. They were exiled to the farthest part of the village. Likewise, with Supri Burung who wrote articles in newspapers in the form of utterances so that people would realize that they were being oppressed. Burung were caught and thrown into custody. Burung is strong enough to face government repression must lose consciousness to become completely silent.

Marginalization occurred within AGTPAZ [5], especially in the character Rara Wilis until he became Pak Wo who had repented. The acceptance of the Ahmadiyya congregation for Rara Wilis, made him learn Islamic teachings, which are considered heretical by residents but behave like a religious person. Focalist Wilis and Pak Wo spoke about the suffering of the outcast. A shemale who is insulted by the community and oppressed by the authorities and an Ahmadi (an adherent of the Ahmadiyah) who is considered heretical has the same fate as a shemale. The marginalization of the life choices of people who are different from most people is a threat to the common good and is considered a counter-hegemony. However, in this novel, the marginalization and humiliation of the counter-hegemony that Wilis and Pak Wo are promoting are given victory through "the hand of God" because of their steadfastness in life.

Based on the three winning novels of the Jakarta Art Council Novel Award 2018, silencing was carried out against counter-hegemony figures and residents. Hegemony is absolute and cannot be contested by those under it. Everything that disturbs him will be silenced and destroyed.

\subsection{Critical Analysis}

Several things need to be underlined because there are things that must be considered regarding writing creativity, as previously explained. It can be seen that in some cases, writers, intentionally or not, bring out their character in their works. Felix K. Nesi shows his courage and positions himself as a writer who makes fun of the government, apparatus, and religious leaders in his works. He tells the ironism of government and religion through his dark, veiled humor. In another case with A. Mustafa, who only described the event as an event, deep anger and disappointment were not shown in the character as a focalist. In fact, during the New Order era, even today, the Ahmadiyya sect of Islam was used to strengthen government authority [2].

$A G T P A Z$ [5] also found a point of ironism regarding Mustafa's unconsciousness towards hegemony in his work. The characters who insult Pak Wo show their ironism because of the corruption cases that appear suddenly without any deep storytelling. Pak Wo's big hope for God dampens demands for security and comfort as a religious adherent to the government. On the other hand, its flatness when prying on history and religion obscures its position as a writer who brings up marginal groups so that they appear "playing safe".

Mochammad Nasrullah reveals himself to be a hegemony in social construction because he continues to put women at the edge of the story. Labeling and depiction of the attitudes of female characters continue to be depicted as bad and not on a par with male characters. It cannot be concluded that Nasrullah gave cynicism or ironism to the position of women because the marginalization of women appeared consistently. Also, counter-hegemony figures in Balada Supri [6] depend on magical things. This concludes that Nasrullah as a writer still has social construction hegemony. 


\section{Conclusion}

Based on the analysis in this research, the three works of the three winners of the Jakarta Art Council Novel Award 2018 tell that the small community becomes weak when it comes to dealing directly with the government and the authorities. In the name of everything as a "state duty", everything that the apparatus does is lawful and cannot be prosecuted for their mistakes. Hegemony also takes shelter behind religion which invites its adherents to be patient and surrender themselves so that God will pay back the sins of the rulers. Religion is the main invisible weapon that can heal the wounds of the lower classes. Social construction is also described as being intertwined as a hegemonic tool to protect its power. Women are easy targets of hegemonic masculinity because their position is weakened and not supported by any party. Women and shemale are still seen as objects.

However, two of the three writers still show hegemonic value in their works. A. Mustafa and Mochammad Nasrullah who present stories against the government show that they are still hegemony. A. Mustafa recounts the suffering of transgender people and Ahmadis as an oppressed minority, but the solutions offered seem to be only to God and religion. Realistic resistance is not presented, thus giving an idea that A. Mustafa is still hegemonic. Mochammad Nasrullah describes his rebel leaders as volunteering to magical powers. Realistic solutions are also presented, but the figures of Djoko Telu, Djoko Tole, and Perompak Djaka still depend on adultery and trust. Also, its consistency insubordination of women without any ironism or cynicism in it makes Balada Supri [6] appear hegemonic.

\section{References}

[1] Anonymous. (2018). Pertanggungjawaban Dewan Juri Sayembara Novel Dewan Kesenian Jakarta 2018. Dkj.or.id. Accessed on February 122020.

[2] [2] Hicks, J. (2014). Heresy and authority: understanding the turn against Ahmadiyah in Indonesia. South East Asia Research, September 2014, vol. 22. no. 3. Hlm. 321-339.

[3] Im, H. G. (1991). Hegemony and counter-hegemony in gramsci. Asian Perspective vol. 15. No. 1 (Spring-Summer). P. 123-156. Lynne Reinner Publisher.

[4] Luxemburg, J. V., Bal, M., dan Weststeijn, W. G. (1991). Tentang Sastra (translated by Akhadiati Ikram). Jakarta: Intermasa.

[5] Mustafa, A. (2019). Anak Gembala yang Tertidur Panjang di Akhir Zaman. Jogjakarta: Shira Media.

[6] Nasrullah, M. (2019). Balada Supri. Jakarta: Penerbit Anagram.

[7] Nesi, F. K. (2019). Orang-Orang Oetimu . Tangerang Selatan: Margin Kiri.

[8] Nurhidayah, D. I. (2019). Hegemoni Kekuasaan dalam Novel Orang-Orang Oetimu Karya Felix K. Nesi: Kajian Sosiologi Sastra. Prosiding Senasbasa vol. 3 no. 2 2019. P. 274-283.

[9] Pihalajaniemi, N. (2017). The Many Faces of Power: The Portrayal of Hegemony in Fight Club by Chuck Palahniuk and American Psycho by Bret Easton Ellis. Finlandia: University of Tampere.

[10] [10] Rosidi, A. (2017). Ikhtisar Sejarah Kesusasteraan Indonesia. Bandung: PT Pustaka Jaya.

[11] Sholihah, L. (2019). Kecenderungan Sayembara Sastra Indonesia. Prosiding Seminar Sejarah Sastra: Memutakhirkan Kajian dan Penulisan Sejarah Sastra. Depok: Universitas Indonesia.

[12] Sutrisno, M., Putranto, H. (2005). Teori-Teori Kebudayaan. Yogyakarta: Penerbit Kanisius.

[13] Tokarczuk, O. (2019). Nobel Lecture by Olga Tokarczuk Nobel Laureate in Literature 2018. The Nobel Foundation 2019. Stockholm: Svenska Akademien.

[14] Wellek, R., Warren A. (2016). Teori Kesusasteraan. Jakarta: PT Gramedia. 